\author{
Слободан С. Јаковљевић \\ Чачак, Србија \\ e-mail: slobodan.jakovljevic244@gmail.com
}

\title{
ФЕНОМЕН ЕФЕМЕРНОГ СПЕКТАКЛА КАРЛОВАЧКЕ МИТРОПОЛИЈЕ- БОГОСЛУЖБЕНИ АСПЕКТИ И БОРБА ПРОТИВ УНИЈЕ
}

\begin{abstract}
Апстракт: Циь овог рада јесте осврт на феномен ефемерног спектакла у Карловачкој митрополији. Сагледавамо га као потребу за опстанком и један од начина борбе против уније. Такође, дајемо ретроспективу и облике оваквог феномена у православљу, обраћајући пре свега пажњу на његове облике у Царској Русији и везу са руским архијерејским богослужењем.
\end{abstract}

Кључне речи: аколутија, архијереј, барок, богослужење, ефемерни спектакл, Карловачка митрополија, церемонијал

\section{Увод}

Свечани дочеци епископа, канонске визитације, као и богослужење у храмовима током визитација, древна су традиција Цркве. Још су апостоли мисионарили и путовали као пастири, поучавали, укрепљивали и духовно снажили хришћане (Дап. 13 и 14; Дап. 15, 22-40; Дап. 15, 36-18, 22; Дап. 18, 22-21, 17; 2 Тим. 3, 11; Гал. 2, 1; 1, 8; 2 Кор. 12, 14; $13,1)$. Њихов долазак подразумевао је свечани дочек, јер се није радило о свакодневном догађају. Помесни сабор у Картагини (419) у свом 52. канону наглашава епископима да свако место под својом јурисдикцијом удостоје обиласка бар једном годишње. ${ }^{1}$ На овај канон наслања се још неколико њих који говоре о потреби епископа да поучава, проповеда и све држи у канонском поретку. ${ }^{2}$ За Светог Василија Великог (329-379) постоје сведочанства да је вршећи своју епископску дужност често обилазио сва места Кесарије Кападокијске, богослужио, мисионарио, бавио се милосрђем и учвршћивао веру у народу. Такође, Блажени Августин (354-430) оставио је сведочанство о томе да му је једна црква била много далека од катедре, те није успевао да је редовно обилази. Стога је успео да издејствује да она добије свога архијереја само да не би остала без редовне посете епископа. ${ }^{3}$

У вековима који су уследили, начини дочека епископа, богослужење и сваки церемонијал који претходи или следи након богослужења поприма облик спектакла.

Развитак церемонијала посебно је уочљив у цркви Свете Софије у Цариграду, где присуство цара утиче чак и на облик богослужења, начин одевања епископа и

1 Свештени канони Цркве 2005, 339-340.

2 Ап. 58; Трул. 19; Сард. 11; Лаод. 19; Карт. 71, 121, 123 (Свештени канони Цркве 2005, 51, 151, 280, 293, 353, 381, 382).

3 Видети: Милаш 1896, 187-188: Милаш 1902, 400. 
богослужбене одежде. ${ }^{4}$ Византијски дворски церемонијал све до XII века и појаве династије Комнина мешавина је римско-персијске традиције. Он је подразумевао заслепљујуће и заглушујуће сценске ефекте. Нарочито приликом приближавања царском престолу које је подразумевало уздизање престола и готово мађионичарско пресвлачење цара. Посебно је било важно пред страним поклисарима испоштовати протоколе, јер је то у ствари био и начин дипломатије - странце засенити спољним сјајем ради појачавања угледа државе. ${ }^{5}$ Развитак обреда Великог входа представља пример конкретног утицаја присуства цара на структуру богослужења. Према неким изворима, у току процесије на Литургији Велике Цркве патријарх би срео цара са Даровима и цар би га том приликом поздравио пожелевши му многа лета. Извесно је да му је патријарх одговарао истом мером. ${ }^{6}$ То је утицало да се приликом вршења Великог входа појаве гласна спомињања током саме процесије. У најстаријој записаној пракси коју имамо само је ђакон излазио на Вход и тихо говорио Све вас, не прекидајући Херувимску песму. У каснијем периоду народ је почео молити свештенство да их помиње, пошто се ближило евхаристијско приношење. Свакако се може закључити да је ова њихова молба условљена чињеницом да се у стара времена Проскомидија вршила пре Великог входа. ${ }^{7}$ Свештеници су очито услишили молбе народу будући да су их почели помињати приликом вршења литије, додуше тихо. Такође, према неким сведочанствима, уколико су Литургији присуствовали император и патријарх, били су гласно споменути током Входа. ${ }^{8}$ То је утицало да се касније умножи број спомињања цара, патријарха, клира, народа итд.

Један од примера ефемерног спектакла карактеристичног за цариградског патријарха јесте, рецимо, његов ход на ждребету на празник Цвети. Обред који је вршен на Цвети након Литургије подразумевао је оживотворавање сцене Христовог уласка на магарету у Јерусалим. Испред патријарха литијски иду клирици и носе у рукама палмове гране и врбове гранчице певајући тропар Свеопште васкрсеље. Литија је подразумевала пут од Свете Софије до храма Светих 40 мученика. Након доласка у храм, патријарх би освећивао гранчице и делио их народу. ${ }^{9}$ Карактеристично је да цар никада није узимао учешћа у овом чину. Још једна занимљивост у вези са овим чином јесте да је прешао у праксу Руске цркве, где је задобио неке локалне особености, између осталих и посебност да је, насупрот византијском, руски цар учествовао у процесији. ${ }^{10}$ Пример посебне врсте ефемерног спектакла који се тиче цара дешавао се када падне Кириопасха. Тада би цар помпезно одлазио на Литургију у Халкопратијску цркву, а након тога је приређиван ручак за дворјане и свештенство. ${ }^{11}$

Примањем православља из Цариграда сигурно је да један од узора српске јерархије у организационом, богослужбеном и сваком другом смислу постаје Цариградска Патријаршија. Конституисање Српске аутокефалне цркве несумњиво је представљало процес дужег трајања. Јасно распознатљив профил архиепископије захтевао је деликатно и практично примерено деловање на преуређењу дотадашње српске сакралне мапе, што је подразумевало како њену појаву на новијим култним местима, тако и утискивање печата

4 Видети студију: Woodfin 2012.

5 Стошић 2003, 225-223; О церемонијалу византијског двора у свим аспектима видети: Constantinus Porphyrogenitus MDCCCXXIX.

6 Голубцов 1907, 215.

7 Taft 1978, 229-230.

8 Исто, 201-202, 173.

9 Дмитријевски 2004, 105-107.

10 Голубинской 1904, 371.

11 Дмитријевски 2004, 111-114. 
институције на старим. ${ }^{12}$ Архитектура, одевање епископа следствено узорима византијске јерархије, познавање дворских протокола, основа дипломатије и учешће у дипломатским процесима, као и присуство на дворским спектаклима, имало је пресудну улогу у постепеној афирмацији овог процеса. Нема никакве сумње да су крунисања владара, освећења њихових задужбина, сахране архиепископа, епископа или владара, садржавале у себи одлике ефемерног спектакла који је своје узоре имао у пракси дворова Византије и Угарске. Присетимо се описа дочека моштију Светог Симеона Мироточивог 1206. године или крунисања Стефана Првовенчаног у Жичи. ${ }^{13}$ Место архиепископа српског као друге најзначајније личности државе Немањића утврдио је Свети Сава. То је подразумевало одређену врсту спектакла коју је изазивала његова појава. То индиректно потврђује и Димитрије Хоматијан (1216-1236) у своме писму упућеном Светом Сави, где (претерујући) пише: „Потпуно се упустио у световне бриге, почео да учествује у гозбама, да јаше коње најплеменитије пасмине, лепе, окићене заставама, да води са собом многу послугу, да се размеће у свечаним поворкама раскошном и разноврсном пратњом. ${ }^{\text {‘14 }}$

\section{Српска јерархија Карловачке митрополије и ефемерни спектакл}

У периоду туркократије српски првојерарси нису били само патријарси - они су и те како били део отоманског политичког апарата, те су следствено томе имали и одређене повластице и права. Тако, пратећи историјска сведочанства, уочавамо записе да патријарси јашу на свечано окићеним коњима, понекад у пратњи јаничара, са топузом окаченим о коња који представља символ власти. ${ }^{15}$ У путопису ђакона Павла Алепског срећемо епизоде у којима се описује сусрет делегације антиохијског патријарха у којој је и сам био са делегацијом српског патријарха Гаврила Рајића (1648-1655). У његовом спису очит је ниподаштавајући тон према Гаврилу Рајићу - на граници у Путвиљу он истиче наводну бахатост и расипање српског патријарха, подмићивање граничара да би прешао границу итд. Уз то, као да се осећа нескривена завист када описује пратиоце нашег патријарха на којима су веома богата одећа и опрема за коње, посребрено оружје и велики товар. ${ }^{16}$

Османлијски систем је, темељећи се на шеријату, на неки начин толерисао црквено-правно устројство Православне Цркве. Тако се отворио простор за политичку сарадњу, без које владавина Османлија не би била могућа. Пећки патријарси били су у обавези да плаћају кесим, тј. порез од 100.000 аспри, што је у том периоду било еквивалентно суми од 2.000 дуката, док је свака промена на патријарашком трону султану доносила додатне приходе, јер би он ту промену потврђивао бератом. ${ }^{17}$ Као носиоци берата, чланови црквене јерархије формално су спадали у феудални слој друштва Османлијског царства. Бератом су до појединости била утврђена и набројана њихова права проистекла из уреднога испуњавања одређених новчаних и политичких обавеза. ${ }^{18}$ Православно свештенство вршило је, тако, судску власт, те су свештеници, на неки начин, посматрани и као државни службеници. ${ }^{19}$

12 Стевовић 2016, 42.

13 Теодосије, Житије Светог Саве 2016, 117-118, 181-190.

14 Благојевић $1989,71$.

15 Тимотијевић $1989,346$.

16 Петровић 2011, 73, нап. 10.

17 Шулетић 2008, 32.

18 Тричковић 1980, 61-163, 69.

19 Andrić 2004, 15. 
Након Велике Сеобе (1690) један део јерархије Српске цркве и народа нашао се у новом политичко-културолошком контексту. Карловачка митрополија као специфичан феномен веома је занимљива за проучавање црквеног ефемерног спектакла. Дочеци епископа и митрополита кретали су се између традиције, утицаја Русије и Духовног регуламента, као и непрекидног упоређивања са римокатоличком јерархијом. ${ }^{20}$ Није се случајно патријарх Арсеније Чарнојевић (1674-1706) у визитацији Марчанске епархије 1692. године појавио са три стотине лепо одевених и украшених, као и богато наоружаних коњаника. Римокатоличка црква и кардинал Леополд Колонић (1631-1707) $)^{21}$ са негодовањем су испратили овај визитациони спектакл и гледали да се не понавља, тако да му је у наредном периоду чак и забрањивано да иде у канонске визитације. У поменику манастира Шишатовца забележено је да му је 1702. године забрањена канонска посета Футогу. Томе су свакако кумовали и затегнути односи са двором. ${ }^{22}$

Ефемерни спектакл у контексту дочека епископа Карловачке митрополије и њихових канонских визитација посматран је углавном као облик позоришне представе где су у главној улози архијереји Карловачке митрополије. Они су принчеви Цркве који су принуђени да глуме на позорници моћи. ${ }^{23}$ Око њих је постављена позоришна сцена. Барјаци, свеће, иконе, рипиде и кадионице представљају елементе у сценској поставци. ${ }^{24}$ Међутим, не ради се ту тек о хиру или израженој љубави према барокном спектаклу српских митрополита и епископа, већ пре свега о потреби коју је наметао животни контекст опстанка. Услови живота прекодунавских Срба били су далеко од идеалних. Привилегије цара Леополда I обећавале су, али само на папиру, доста верских и политичких слобода. ${ }^{25}$ Међутим, читава историја Карловачке митрополије у ствари је борба за признавање и потврђивање једном издатих привилегија. Несигурност постојања у Католичкој Царевини допринела је да су Срби првих година били без јасног политичког одредишта, надајући се повратку у домовину. ${ }^{26}$ „Под влашћу моћнијег суверена српска етнија имала је потребу са доказивањем свог легитимитета. Све то утицало је на развитак спектакла (који је пратио митрополите) као неочекиване изражајности Карловачке митрополије.“27 Угрожена милитантном унијатском пропагандом којој је српски народ непрекидно био изложен, Црква преко Дунава трудила се да парира римокатоличкој у сваком сегменту, па и у спољашњем сјају. У супротном могло би се десити нешто што би наликовало ситуацији пре појаве Петра Могиле у Малој Русији. Присетимо се: један од судбоносних догађаја на територији Украјине одиграо се 1596. године када је БрестЛитовска унија омогућила стварање унијатских цркава источног обреда. Вођени духом криптороманизма многе владике пришле су овоме покрету, али и већина позападњачених племића, као жељеном путу у сопствено укључење у западну цивилизацију. ${ }^{28}$ Богослужбено стање Малорусије тога времена било је веома лоше: сујеверје је избијало одасвуд, многи обреди сумњиве вредности постали су веома популарни (на пример, врло

20 Тимотијевић 1989, 340.

21 Један од најважнијих црквених великодостојника у Угарској XVII-XVIII века. Био је на челу антиправославно расположеног римокатоличког клира који је радио на унијаћењу православних Срба. Само пар година након добијања привилегија његове присталице су их отворено кршиле ( Ћоровић 2011, 455).

22 Поповић 1954, 74-75.

23 Милошевић 2019, 74-75.

24 Тимотијевић $1989,364$.

25 Давидов 1994, 39-43.

26 Тодоровић 2010, 20.

27 Исто, 19.

28 Meyendorff 1985, 102-103. 
често било је причешће Светом водом на Богојављење; у овом периоду проширила се и пракса клечања на Великом входу, која је произашла из веровања да су хлеб и вино већ освећени на Предложењу; распрострањено је било и веровање у клетве и амајлије). Цркве су биле сиромашне и прљаве, одежде свештеника дроњаве, док су литургијске утвари често недостајале. Свештеници су били слабо образовани, нарочито у поређењу са латинским клиром. Стога не зачуђује зашто је римокатолицизам, као државна религија, постајао све привлачнији, нарочито за више класе. ${ }^{29}$ Да не би дошло до овога морало се радити и на спољашњем изгледу целокупног живота Цркве, укључујући веома свечане процесије приликом дочека епископа, посебно митрополита, архитектуру, одећу, унутрашњи изглед цркава и епископских дворова. Јован Рајић у свом делу Историја Катихизма Православних Србаља у Цесарским државама даје један опис који нам помаже да разумемо овај феномен: „Јоште тада из турштине изнешена грубост у оделу свештеничком, ради које су иноверни нашем клиру ругали се и презирали га побудила је архипастира (Мојсија Петровића) да и тај порок одврати од клира и одело му преустроји. “30 У овом кратком опису осећа се моменат нелагодности, па чак и стида пред другачијом културном средином и бојазни од исмевања. Из истог разлога и патријарх Арсеније IV, на одређени начин, напада народске иконописце, самоуке замазиваче, чија дела под претњом анатеме забрањује куповати. И овде је присутан културолошки стид јер овакво сликарство, неуко и неформирано, представља саблазан за друге конфесије. ${ }^{31}$ Али не само саблазан, него, рекло би се, пре свега, опасност за опстанак вере. Као и у Украјини, постојала је опасност да римокатолицизам као државна вера постане привлачнија православним Србима, као нека врста улазнице у токове западне цивилизације. Све то је и те како утицало да се Карловачка митрополија претвори у једну праву барокну ecclesia militans и да искористи све што јој је било на располагању у борби за опстанак.

Феномен ефемерног спектакла у Карловачкој митрополији у пуном тону заживљава у периоду Мојсија Петровића (1718-1730) и Викентија Јовановића (17311737), а кулминацију доживљава током столовања Павла Ненадовића (1749-1768). Слеิдећи примере својих претходника, Павле Ненадовић прихвата концепције барокне патронаже чије су основе поставили још на свом двору рани Медичи. Од Томе Аквинског, који је први класификовао величајност као врлину, посезало се до Аристотелове „Никомахове етике“, где су тражене потврде за тумачење politica di magnificenza као кнежевске врлине. На основу магнифицезе дошло се до свеукупног схватања политике дворског живота која се темељила на идејном програму дворског самоприказивања. Карловачки и београдски митрополити упустили су се у такмичење са државним и верским достојанственицима усвајајући протоколе барокне репрезентације. ${ }^{32}$ Према тим схватањима започиње градња монументалних владичанских дворова и цркава. Такав приступ грађевини и архитектури сматран је врлином. ${ }^{33}$ Митрополити мењају навике одевања, појављују се у свиленој и пурпурној одећи угледајући се на римокатолички клир. Одећа се шила у Бечу и Карлсбаду, а сасвим ретко у Београду. По свему судећи, начин одевања испровоцирао је васељенског патријарха да укори београдске митрополите да не носе помодно и скупо одело, већ уредно и како пристаје канонима. ${ }^{34}$ Исто се очитавало и у унутрашњем уређењу епископских дворова. Такође, сахране

29 Исто, 103-104.

30 Преузето из: Вукашиновић 2017, 82.

31 Исто, 83.

32 Тимотијевић 1987, 113; Тимотијевић 1989, 358-359.

33 Медаковић 1988, 193-205; Милошевић 2019, 81-91.

34 Милошевић 2019,76-77. 
митрополита и епископа обављају се у складу са фунералним спектаклом који је у оквиру Монархије био добро познат и општеприхваћен. ${ }^{35}$ Митрополити су у складу са тадашњим обичајима наручивали раскошне аутопортрете, као и портрете својих претходника. Портрети су одсликавали друштвену реалност указујући поштовање хабзбуршким ауторитетима, те су формирали визуелну потку сарадње са монархијом. ${ }^{36}$

Описи церемонијалних дочека епископа вероватно су најважнији и најзанимљивији део феномена барокног ефемерног спектакла. Канонске визитације нису представљале сасвим нов елемент церемонијалне културе у Митрополији, за разлику од погребних процесија или тријумфалних улазака. Чин свечаног дочека почињао је пред манастирском капијом где митрополита дочекују одабрани представници. Најпре, ту је било мноштво народа, не само из тог места, већ и са других страна. Обавезно су били присутни болесници и просјаци које је митрополит обилно даривао, што је носило јасну символику Доброг Пастира. Након тога формира се процесиона поворка на чијем челу је митрополит и која наравно, иде ка централној тачки литије - храму. Сигурно да је митрополит до цркве ишао споро и пут је трајао дуго, а успут је морало бити и неколико станица приликом којих је он благосиљао окупљени народ и поздрављао угледне представнике власти и војске, чије је присуство на визитацијама засведочено. ${ }^{37}$ Примера ради, записано је да Павле Ненадовић стиже у Шишатовац у предивним позлаћеним кочијама у које је упрегнуто шест веома лепих и свечано украшених коња. Формира се процесиона поворка ка храму на чијем је челу митрополит обучен у одежде. Наравно, у процесијама су присутни барјаци, иконе, рипиде, свеће... Посете Шишатовцу у неколико наврата подразумевале су говорење поучног слова, читање молитава за болеснике и читање акатиста Пресветој Богородици. Сутрадан би била служена архијерејска Литургија. Према сведочанствима, приликом једне од посета, након Литургије служен је парастос ктиторима манастира, затим су уприличени пренос моштију Стефана Штиљановића, освећење кивота и полагање моштију у нови кивот, а све је завршенно литијом са моштима. ${ }^{38}$ За Павла Ненадовића је забележено да је на Богојављење 1754. године веома свечано одслужио Свету архијерејску литургију са два епископа, четири архимандрита, протосинђелима, синђелима и много ђакона. Потом су литијски изашли на Дунав, где је извршено Велико водоосвећење. ${ }^{39}$ Посебну врсту ефемерног спектакла у складу са барокним обрасцем свечаног представљања и обичајима живота на двору представља тријумфалан улазак у град приликом повратка, најчешће са Бечког двора. У контексту тог спектакла град је жижа церемонијала. Украјинац Мануило Козачински организовао је свечани дочек митрополиту Викентију Јовановићу у част повољног исхода митрополитове посете Бечу где је од Карла VI добио потврду српских привилегија. Током доласка звонила су звона, певани псалми, а ученици су стајали у шпалиру са цвећем. На челу процесије ишао је митрополитов шестопрег, свештенство је свог митрополита дочекивало у одеждама, народ са рипидама и барјацима. Кулминација овог дочека била је Света Литургија, као и проповед у склопу ње. ${ }^{40}$ Богослужење у контексту барокног ефемерног спектакла карловачких митрополита има и своју политичко-националну димензију. Сукоб са Турцима фигурура као омиљени мотив у овим приликама. Тако се након Евхаристије поје Тебе Бога хвалим у Петроварадину 1717. године као молитвена

35 Тодоровић 2010, 164-166; Тимотијевић 1989, 359.

36 За детаљније податке видети: Васић 2012.

37 Видети: Тимотијевић 1989, 362-363.

38 Исто, 353, 361-364.

39 Вукашиновић 2017, 237.

40 Тодоровић 2010, 158-159. 
захвалност због победе над Турцима. У Земуну се 30. јула 1754. године служи бденије за деспотицу Ангелину и молитве да Бог Србима поврати оне делове њихове земље које су им Турци одузели, где се пре свега мисли на Београд. ${ }^{41}$ По свему судећи, ефемерни спектакли у Карловачкој митрополији били су прва форма овог феномена код Срба, и те како утичући на касније врсте ефемерног спектакла у време владавине кнезова Милоша и Михајла, а сасвим сигурно и каснијих српских владара. ${ }^{42}$

\section{Ефемерни спектакл у Руској цркви - веза са богослужењем}

Баш због тога што су се дочеци епископа и митрополита кретали између традиције, утицаја Русије и Духовног регуламента, као и непрекидног упоређивања са римокатоличком јерархијом, потребно је видети како је овај феномен изгледао у руској средини. Знамо да су српски архијереји често путовали у Русију ради сакупљања милостиње или тражења разних врста помоћи попут књига или учитеља. Током таквих путовања сасвим сигурно су саслуживали и имали прилику да учествују у њиховим процесијама или неким другим формама ефемерног спектакла. Не би требало пренебрегнути закључак да је ту било одређених утицаја, поготово што је ефемерни спектакл у руском облику био још раскошнији и грандиознији. Не постоје поуздана сведочанстава о дочецима кијевских и московских митрополита у периоду XIV-XV века, али све указује на скромне и једноставне начине уласка у храм. Одређену помпезност и усложњавање овога обреда уочавамо у периоду XVI-XVII века. ${ }^{43}$ То се свакако може посматрати као последица, са једне стране, телетургијског развоја, а са друге, чињенице да је служби епископа у том периоду придаван веома велики значај. ${ }^{44}$ Тада можемо говорити о једној сакралној представи или церемонијалу. Начин дочека постао је изузетно свечан. Гледало се да литија до цркве буде што дужа. Заправо, архијерејски двор је готово по правилу био знатно удаљен од катедралног храма, па се понекад морало проћи и кроз цео град. Карактер и поредак ове церемонијалне литије зависио је од величине празника, месних услова, као и од личне воље предстојатеља. Пре доласка епископа звонила би звона и окупљала народ. Ту је било ученика, представника месних власти, бојара, војвода у најсвечанијој одећи. Временом, током овако дугих литија, појављује се обичај читања молитава, псалама и тропара, у чему су учешће узимали и деца и ђаци. ${ }^{45}$ Сам обред би започињао звоњењем, које је означавало улазак чтечева са свећама у архијерејски двор. У двору су се такође окупљали свештеници крстоносци, ђакони и понеко од државних чиновника. У врло ретким случајевима, када би, рецимо, новопостављени архијереј вршио прву службу, у двор би долазили и обласни господари, бојари и војводе, као и виђенија властела. ${ }^{46}$ Приликом изласка из келије архијереј би започињао са читањем молитава и читавог низа тропара, чији су број и садржина зависили од растојања и разних етапа пута. Непосредно пре самог почетка читања он би најпре застао и благосиљао окупљени народ, па би потом наставио литију. ${ }^{47}$ Занимљив је извор из XVI века који говори о предвиђеном дочеку новопостављеног казањског архиепископа Светог Гурија (1555-1563). У њему се упућује на то да сам дочек треба да буде ванредно торжествен не

41 Вукашиновић 2017, 237.

42 Видети: Timotijević 1988, 305-312.

43 Голубцов 1907, 153.

44 Красносељцев 2015, 21.

45 За детаљније видети: Голубцов 1903, 501.

46 Голубцов 1907, 155.

47 Исто, 158. 
само у Казању, него и у успутним градовима Коломњу и Свијажску. Према истоме извору, Гурије би требало да чита Јеванђеље пред градским вратима, затим да по јектенији и молитви народ осењује Крстом и кропи освећеном водом, након тога да се, идући до цркве, поју црквене песме, а да после Литургије оде на градске зидине, да обиђе цео град, да над вратима врши разна мољења ради очувања града и да градска врата покропи освећеном водом. ${ }^{48}$

Нарочито свечане литије и дочеци засведочени су у седишту руског патријарха. Тако се описује да у време патријарха Никона њему саслужују 54 до 84 архимандрита, игумана, свештеника и ђакона. Сав црквени мобилијар и начин облачења уклапан је према царским свечаним оделима. Постојале су, тако, три поставке: велика, средња и мања. Разлика је била у квалитету материјала, јачини боје, скупоћи бисера и драгог камења које их украшава. Чак су се и појци приликом великих празника одевали у златне стихаре. ${ }^{49}$

Једна богослужбена занимљивост и веза са свим овим церемонијалима јесте аколутија уласка у храм, која се развила у прениконовској Русији и која је била интегрални део архијерејског богослужења руске праксе. На формирање структуре овог чина уласка без икакве сумње утицао је начин дочека епископа у Московској митрополији (патријаршији) средњег века. Стога је занимљиво видети како је то богослужбено изгледало у Руској цркви. Једна од карактеристичних одлика прениконовских архијерејских чиновника ${ }^{50}$ јесте мноштво молитава које се читају пре саме Проскомидије. Постоје мишљења да почетак изговарања молитава приликом идења ка храму и уласка у храм треба тражити у XI веку. ${ }^{51}$ За ову аколутију може се рећи да представља пример Баумштарковог закона литургијске еволуције, јер се староруски чин уласка у цркву развија од једноставне ка опширној верзији. ${ }^{52}$ Кипријанова редакција Филотејевог Диатаксиса имала је једноставан обред уласка у храм. Преписивања после Кипријана су, у малим варијацијама, и даље садржала филотејевску једноставност. Међутим, у периоду од XV до XVII века у служабним књигама почиње комбиновање Филотејевог почетка са псалмима и мноштвом молитава. ${ }^{53}$ Такве молитве поделиле су се у две групе - на путу ка цркви и након уласка у њу. У попису тропара, молитава, псалама и осталог што чини поредак уласка у храм, у неким преписима може се наћи и преко двадесет појединачних читања која би архијереј изговорио у томе ходу, а који је почињао када устане од постеље. Истраживањем је утврђено да постоји чак седам различитих варијанти овог почетног дела Литургије. ${ }^{54}$ Један од циљева Стоглавог сабора (1551) био је да унификује овај чин, али без успеха - различити облици наставили су да сапостоје. ${ }^{55}$ Овај чин уласка је био богослужбени процес који је служио функцији једнодневног спектакла у месту где је архијереј служио Литургију, а поменуте станке и молитве које су читане утицале су да се аколутија уласка развије до раскошних дочека о којима смо већ писали. Ефемерни спектакл и аколутија уласка извршили су међусобно прожимање.

Што се тиче структуре ове аколутије она укратко изгледа овако: након изласка из келије архијереја су чекали свећеносци и појци који узимају благослов и тада почиње

48 Видети: Красносељцев 2015, 25.

49 Видети: Голубцов 1908, 147-213.

50 Данас би рекли старообредничких архијерејских чиновника. За више о старообредничким књигама видети: Кончаревић 2006, 157-186.

51 Jones, Wainwright,Yarnold, 1992, 219.

52 Larin 2011, 18.

53 Larin 2010,134.

54 Дмитриевский 1884, 57-74: Sipovich 1978, 155-56.

55 Meyendorff 1991, 133. 
ход ка цркви који подразумева читање и појање мноштва молитава, псалама, тропара. Пред црквом архијереја дочекује протођакон са кадионицом и наставља се са читањем молитава испред храма. Следе обреди након уласка у храм и облачење архијереја. Структура ових молитава упућује на њихов покајничко-аскетски карактер. Занимљиву форму аколутије уласка примећујемо у малоруском Гркокатоличком чиновнику из 1716. године, где пише да се архијереј моли на путу ка цркви, а да се приликом уласка у њу кропи Светом водицом. Ту је идеја очишћења свакако најизраженија. ${ }^{56}$ А. А. Дмитријевски у древним рукописима, па и у Барберинском кодексу, проналази неке од молитава ове аколутије или молитве сличног садржаја. Такође наводи да се неке од њих могу пронаћи у старим грчким рукописима (у чину исповести, молитвама пред Причешће или молитвама за разне случајеве). Занимљиво је да он изражава наду да би у будућности могао да се у древним грчким споменицима појави предложак оваквог поретка. ${ }^{57}$ До данас ништа слично није пронађено, тако да се о грчком поретку као извору обреда ипак не може говорити. Међутим, како В. Ларина примећује, постоји занимљива сличност између чина уласка са Preparatio ad Missam тридентске мисе (1570), али свака теза о евентуалном утицају Запада на формирање оваквог чина захтева озбиљно истраживање. ${ }^{58}$ На крају ваља споменути и мишљење да на прениконовску аколутију уласка у храм треба гледати као на развојни ток церемонијалног уласка цара у Цркву Свете Софије у Х веку. Из сведочанства Харуна Ибн Јахија, арапског путника који је боравио у Цариграду, можемо видети како је то изгледало: Када год би цар направио два корака, запевали би Сети се смрти. Када год би се ово изговорило, ияар би отворио кутију коју је носио са собом и у којој је била земља, пољубио би земљу, заплакао се и продужио даље. Ово би се понављало на свака два корака. ${ }^{59}$

Ово мноштво молитава укида се Никоновом реформом, тј. њихов број бива сведен на минимум. ${ }^{60}$ Малоруска издања од 1604. године и издања Стрјатинског служабника, преко даљих издања (Вилна 1617, Служабник Петра Могиле 1629. и 1639. године, Лвов 1637. и 1646) садрже овај чин у скраћеном облику.

Оно што је нама веома занимљиво у контексту Карловачке митрополије јесте чињеница да су овакви прениконовски архијерејски чиновници преписивани у Карловачкој митрополији и да су сигурно коришћени, те да и ту може постојати веза са развитком свечаних процесија. Они су по својој структури погодовали спектакуларном дочеку епископа и дужим процесијама. Да су наши архијереји заиста и употребљавали архијерејске чиновнике овог типа и по њима служили, потврђује и запис у рукопису МСПЦ $252^{61}$ који потиче из 1734. године и који сведочи да је књига припадала Никанору Мелентијевићу, епископу печујском (1710-1721). ${ }^{62}$ Архимандрит Сава Очинић, потоњи владика црногорски, преписао је 1692. године архијерејски чиновник прениконовске редакције за тадашњег митрополита Висариона (данас се чува у Архиву САНУ под бројем 16). ${ }^{63}$ Архијерејски чиновник исте редакције преписан је 1706 . године и у Босни. ${ }^{64}$ Међутим, нису само српски архијереји користили овакве архијерејске чиновнике

56 Larin 2010, 169.

57 Дмитриевский 1884, 74.

58 Larin 2011, 18, нап. 42.

59 Цитирано према: Larin 2010, 170.

60 Baumstark 1958, 19-23.

61 Архијерејски чиновник, МСПЦ (Збрика рукописа у Музеју Српске Православне Цркве), 252 л, 796. 62 За детаљно о прениконовским архијерејским чиновницима код Срба и могућим везама патријарха Арсенија Чарнојевића са Рачанима као преписивачима оваквих чиновника видети: Јаковљевић 2017, 140-150; Јаковљевић 2019, 235-246.

63 Стојановић 1992, 16-17.

64 Желтов 2003, 215. 
деценијама после богослужбене реформе патријарха Никона. Сличан архијерејски чиновник користио је и Свети Димитрије Ростовски, а епископ је постао тек 1701. године, односно неколико деценија након богослужбене реформе патријарха Никона. ${ }^{65}$

\section{Закључак}

Феномен барокног ефемерног спектакла у Карловачкој митрополији несумњиво је настао из потребе за опстанком, али је истини за вољу имао и одређену предисторију још од Немањића, а православне узоре у Царској Русији. Спектакл по својој дефиницији пружа ескапистички простор и могућност заустављања времена свакодневнице. Раскошне утопије често су припадале друштвима, ентитетима или народима који су са посебним жаром морали да наново доказују сопствену исправност и легитимност. ${ }^{66}$ Прошлост је у Карловачкој митрополији и надахнуће и темељ ефемерног спектакла. Понављање узора ствара привид непрекинутог следа од XV до XVIII века. У свим наведеним примерима слика историје и прошлости оживљена је и модернизована да би оставила дубљи утисак на верника који би требало да осети спој прошлог и садашњег времена. Прошлост и садашњост требало је стопити у славу српског народа, без обзира што је она у то време била само једна етнија у сенци моћног Хабзбуршког царства. ${ }^{67}$

Барок је доба које пружа један нови, универзални културни модел. У томе леже сва његова снага и виталност као светског феномена. Културу Карловачке митрополије морамо сагледавати као интегрални елемент универзалног барока, а ефемерни спектакл као једну од најочитијих одлика. Ваља истаћи да се од средине XVIII века српска култура и уметност латинизују и приклањају бароку више преко Русије и Украјине, индиректно, него директно, преко Аустрије и Угарске, на чијој територији Срби тада живе. Стапање вишевековне црквене праксе са бароком у свим својим феноменима утицало је на убрзани процес мењања богословских парадигми српске православне теологије, а што је почело да убира плодове у деценијама и вековима коју су уследили, ${ }^{68}$ док је, са друге стране, извршено стапање са барокним уметничким идиомом. У том процесу Карловачка митрополија није производила инфериорне одблеске, већ је, напротив, дала своје равноправно уметничко сагледавање, али и драгоцено тумачење друштва у спектаклу. ${ }^{69}$

\section{Извори}

Архијерејски чиновник, МСПЦ (Збирка рукописа Музеја Српске православне цркве), сигнатурни бр. 252 (1686)

Свештени канони Цркве (2005), превод са грчког и словенског епископа Атанасија, умировљеног херцеговачког, Београд: Митрополије и Епархије: Црногорскоприморска, Дабро-Босанска, Новограчаничка, Бачка, Далматинска, ЗахумскоХерцеговачка и Приморска, Православни богословски факултет Београдског универзитета, манастир Тврдош

Constantinus Porphyrogenitus, De cerimoniis aulae Byzantinae libri duo, Bonnae, impensis ed weberi, MDCCCXXIX

65 Исто.

66 Тодоровић 2010,173

67 Тодоровић $2011,142-143$.

68 О свим аспектима тог феномена видети: Вукашиновић 2017.

69 Тодоровић 2010, 174. 
Теодосије, Житије Светог Саве (2016) - (приредио Данијел Дојчиновић), Бања Лука: Владимира Стијак Илисић

\section{Литература}

Andrić, Ivana (2004): „Položaj Pećke patrijašije u Osmanskom carstvu od 1557. do 1690. godine“, Povjesni prilozi, Zagreb: Hrvatski institut za povjest, 71-90.

Baumstark, Anton (1958): Comparative Liturgy, Westminster - Maryland: The Newman press

Благојевић, Милош (1989): Србија у доба Немањића, Београд: Вајат

Васић, Катарина (2012): Портрет српских архијереја у Карловачкој митрополији (1690-1790), докторска дисертација, Београд

Вукашиновић, Владимир (2017): Српска барокна теологија, Београд - Врњци: Универзитет у Београду, Православни богословски факултет, Институт за литургику и историју уметности: Интерклима графика

Woodfin, Warren (2012): The Embodied Icon - Liturgical Vestments and Sacramental Power in Byzantium, Oxford - New York: Oxford University press

Голубинской, Евгений (1904): История русской церкви, т. I, часть II, Москва: Императорского общества истории и древностей российских при Московском университете

Голубцов, Александр (1903): „Об особенностях архиерейского служения Литургии с точки зрения древнецерковного обряда: [Актовая речь]“, Богословский вестник, т. 1, № 3, Сергиев Посад: Московская духовная академия, 499-515.

Голубцов, Александр (1907): Соборные Чиновники и особенности службы по ним, Москва: Императорского общества истории и древностей российских при Московском университете

Голубцов, Александр (1908): Чиновники московского Успенского собора и выходы патриарха Никона, Москва: Синодальная типография

Давидов, Динко (1994): Српске привилегије дома Хабзбуриког, Београд - Нови Сад: Балканолошки институт, Матица Српска

Дмитриевский, Алексей (1884): Богослужение в Русской Церкви в XVI веке. Часть I: Службы круга седмичного и годичного и чинопоследования таинств, Казань: Казанская Духовная академия, 57-144, 419-427.

Дмитријевски, Алексеј (2004): „Ход констатинопољског патријарха на ждребету на Цвети у IX и X веку“, у: А. А. Дмитријевски, Спознајући тајну Крста и Васкрсења Господюег - изабрани чланци и студије, Крагујевац: Каленић, 105-114.

Желтов, Михаил (2003): Архиерейский чин Божественной литургии: история, особенности, соотношение с ординарным («иерейским») чином, Богословский сборник № 11, Москва: Изд. Православного Свято-Тихоновского Богословского института Москва, 207-240.

Јаковљевић, Слободан (2017): „(Не)читљивост култура - Старообредничке књиге међу Србима с краја 17. и почетка 18. века“, у: Старе и нове границе Европе идентитетска истраживања /међународна конференција/, ур. Владимир Вукашиновић, Београд: Институт за културу сакралног МОНС ХЕМУС и ИНСТИТУТ ЗА ЛИТУРГИКУ И ЦРКВЕНУ УМЕТНОСТ Православног Богословског факултета Универзитета у Београду, 140-150. 
Јаковљевић, Слободан (2019): Архијерејски чиновници и литургијари рачанских скриптора у литургијском животу Српске Цркве XVII века и прве половине XVIII века, Београд - Врњци: Центар за литургичке студије MONS HAEMUS, и ИНСТИТУТ ЗА ЛИТУРГИКУ И ЦРКВЕНУ УМЕТНОСТ Православног Богословског факултета Универзитета у Београду

Jones, Cheslyn, Wainwright, Geoffrey, Yarnold, Edward (1992): The Study of Liturgy, London SPCK: Oxford University Press

Кончаревић, Ксенија (2006): „Руско старообредништво кроз призму лингвокултурологије (оглед функционалне анализе)“, Црквене студије 3, Ниш: Центар за црквене студије, 157-186.

Красносељцев, Николај (2015): Путевима богослужбеног хода Православне Цркве кроз историју, Крагујевац: Каленић

Larin, Vasa (2010): ,, The Hierarchal Divine Liturgy in Arsenij Suxanov’s Proskinitarij: Text, Translation, and Analysis of the Entrance Rites", Roma: Orientalia Christiana Analecta, 286.

Larin, Vasa (2011): „The Hierarchal Liturgy in Late Vyzantium and After: Toward a Liturgical Eclisiology“, St. Vladimirs Theological Quarterly, 55: 1, New York: The Faculty of St. Vladimir's orthodox theological seminary, 5-26.

Медаковић, Дејан (1988): „Српски митрополијски дворови“, у: Барок код Срба, Загреб: Просвјета, 193-205.

Meyendorff, Paul (1991): Russia, Ritual and Reform: The Liturgical Reforms of Nikon in the $17^{\text {th }}$ century, New York: St Vladimir's Seminary Press

Meyendorff, Paul (1985): „The Liturgical Reforms of Pether Moghila”, St. Vladimirs Theological Quarterly 2, New York: The Faculty of St. Vladimir's orthodox theological seminary, 101-114.

Милаш, Никодим (1902): Православно ирквено право, Мостар: Издавачка књижница Пахора и Кисића (прештампано: Београд - Шибеник, децембар 2004)

Милаш, Никодим (1896): Правила православне цркве са тумачењима, књига II, Нови Сад: Наклада књижаре А. Пајевића

Милошевић, Ана (2019): „Београдски митрополити на барокној позорници“ у: Барокни Београд - преображаји 1717-1739, Београд: Музеј града Београда и Археолошки институт, 74-95.

Петровић, Далибор (2011): „Однос руске духовне и свјетовне власти према пећком патријарху Гаврилу Рајићу“, Теолошки погледи 3, Београд: Свети Архијерејски Синод Српске Православне Цркве, 69-83.

Поповић, Ј. Душан (1954): Велика Сеоба Срба 1690, Београд: СКЗ

Sipovich, Ceslaus (1978): The Pontifical Liturgy of St John Chrysostom, London: The Francis Skaryna Byelorussian

Стевовић, Иван (2016): „Прве српске епископске цркве (запажања о историји и архитектури)“, Зборник Матице српске за ликовне уметности 44, Нови Сад: Матица српска, 41-60.

Стојановић, Љубомир (1922): Каталог рукописа и старих итампаних књига, Збирка Српске краљевске академије, 1-4, Београд: Српска краљевска академија

Стошић, Љиљана (2003): „Поклисари код Јужних Словена“, Данища 11, Београд: Вукова задужбина, 225-233.

Taft, Robert (1978): The Great Entrance: A History of the Transfer of Gifts and Other Pre-anaphoral Rites, Vol II, in: A History of Liturgy of St. John Chrysostom, sec. ed., Roma: Orientalia Christiana Analecta 
Тимотијевић Мирослав (1989): „Визитација манастира Шишатовца у XVIII веку - прилог истраживању ефемерног спектакла“, у: Манастир Шишатовац, Зборник радова, Београд: Балканолошки институт Српске академије наука и уметности, 341-366.

Timotijević, Miroslav (1988): „Efemerni spektakl za vreme vladavine kneza Miloša i Mihajla Obrenovića“", Peristil 31, Zagreb: Društvo povjesničara umjetnosti Hrvatske, 305-312.

Тимотијевић, Мирослав (1987): „Идејни програм зидног сликарства у припрати манастира Крушедола“, Саопштења XIX, Београд: Републички завод за заштиту споменика културе, 109-126.

Тодоровић, Јелена (2010): Ентитет у сенци (Мапирање моћи и државни спектакл у Карловачкој митрополији), Нови Сад: Палтонеум

Тодоровић, Јелена (2011): „Прошлост коју су изгубили - манипулација прошлошћу и у политичком програму Карловачке митрополије“, Култура 131, Београд: Завод за проучавање културног развитка, 134-144.

Тричковић, Радмила (1980): „Српска православна црква средином XVII века“, Глас Српске академије наука и уметности, књ. 2, Београд: Српска академија наука и уметности, 61-163.

Ћоровић, Владимир (2011): Историја Срба, Београд: Невенка Антић

Шулетић, Никола (2008): Пећка патријаршија крајем XVII и почетком XVIII века, магистарски рад, Београд 


\section{Slobodan S. Jakovljević}

\section{THE PHENOMENON OF THE EPHEMERAL SPECTACLE OF THE METROPOLITANTE OF KARLOVCI - THE DIVINE SERVICE'S ASPECTS AND THE STRUGGLE AGAINST THE UNIATISM}

The intention of this work is to review the phenomenon of the ephemeral spectacle in the Metropolitanate of Karlovci. We consider it as a need for survival and as a one of the struggling ways against the Uniatism. Also, we give a retrospective and forms of such a phenomenon in Orthodoxy, paying attention primarily to its forms in Emperial Russia and the connection with the Russian Episcopal Divine service. 